\title{
Cloned HTLV-1+CD4+, but not CD8+, T-cells display an oncogenic miRNome
}

\author{
Céline Vernin ${ }^{1}$, Christiane Pinatel ${ }^{2}$, Nicolas Nazaret ${ }^{3}$, Eric Wattel ${ }^{1}$, Catherine Legras-Lachuer ${ }^{3}$, Franck Mortreux ${ }^{1 *}$ \\ From 15th International Conference on Human Retroviruses: HTLV and Related Viruses \\ Leuven and Gembloux, Belgium. 5-8 June 2011
}

HTLV-1 persistence in vivo relies on the persistent clonal expansion of its host cells. These are CD4+ and CD8+ T cells, yet ATL is regularly CD4+. Accordingly, untransformed HTLV-1+CD4+ but not CD8+ T cells cloned from carriers cumulate the features of preleukemic cells, including multinuclearity, chromatin bridges, increased cell cycling and inappropriate telomerase activity. MicroRNAs (miR) modify the maturation of a plethora of T-cells RNA and their deregulation would therefore constitute an appropriate explanation for the Tax-dependent or -independent pleiotropic changes in the phenotype of HTLV-1+CD4+ T cells. As the miRNome of naturally infected untransformed cells has not been investigated to date, we assessed the miR expression profiling of $\mathrm{T}$ cells cloned from carriers. Microarray results, confirmed by quantitative RTPCR, showed that, upon infection, CD4+ and CD8+ clones yielded aberrant expression of 15 distinct miRs including miR-34b and miR-494 that were respectively over- and underexpressed in both compartments. The more prominent effect of the infection consisted in the CD4+-restricted overexpression of the cancer-related miRs miR-21, -27b and -23b associated with the CD4+-restricted downregulation of the proapoptotic miR-15 and -16. Data were extended by the analysis of 40 additional CD4+ clones (20 infected). Crossing the miRNome against the whole transcriptome data identified putative miR-targeted genes. In silico, those targeted by miR-23b and $-27 b$ defined 2 hitherto unknown pathways involving the cell cycle and genetic disorders. Therefore HTLV-1 triggers a phenotype-specific miR signature consistent with the preleukemic HTLV-1+CD4+ phenotype.

\footnotetext{
* Correspondence: franck.mortreux@ens-lyon.fr

'Oncovirologie et de Biotherapies, UMR5239 CNRS/ENS Lyon/UCBL/HCL, Hopital Pierre Benite, Lyon, France

Full list of author information is available at the end of the article
}

\section{Author details}

'Oncovirologie et de Biotherapies, UMR5239 CNRS/ENS Lyon/UCBL/HCL, Hopital Pierre Benite, Lyon, France. ${ }^{2}$ Oncovirologie et de Biotherapies, Centre Léon Berard, Lyon, France. ${ }^{3}$ ProfileXpert, Neurobiotec Service, Bron, 69500, France.

Published: 6 June 2011

doi:10.1186/1742-4690-8-S1-A169

Cite this article as: Vernin et al:: Cloned HTLV-1+CD4+, but not CD8+, Tcells display an oncogenic miRNome. Retrovirology 2011 8(Suppl 1):A169.
Submit your next manuscript to BioMed Central and take full advantage of:

- Convenient online submission

- Thorough peer review

- No space constraints or color figure charges

- Immediate publication on acceptance

- Inclusion in PubMed, CAS, Scopus and Google Scholar

- Research which is freely available for redistribution

Submit your manuscript at www.biomedcentral.com/submit

\section{() Biomed Central}

\section{Biomed Central}

(c) 2011 Vernin et al; licensee BioMed Central Ltd. This is an open access article distributed under the terms of the Creative Commons Attribution License (http://creativecommons.org/licenses/by/2.0), which permits unrestricted use, distribution, and reproduction in any medium, provided the original work is properly cited. 